Koch, Lauge (1929b) Stratigraphy of Greenland. Meddr Gr $\phi$ nland, Bd. 73, Afd. 2, Nr. 2 .

Noe-Nygaard, A. (1934) Stratigraphical outlines of the area round Fleming Inlet (East Greenland). Meddr Grфnland, Bd. 103, Nr. 1.

Rosenkrantz, A. (1929) Preliminary account of the geology of the Scoresby Sound district. In Koch, Lauge. The geology of East Greenland. Meddr Grфnland, Afd. 2, Nr. 1, 135-154.

Rosenkrantz, A. (1934) The Lower Jurassic rocks of East Greenland; Part I. Meddr Grфnland, Bd. 110, Nr. 1.

Spath, L. F. (1932) The invertebrate faunas of the Bathonian-Collovian deposits of Jameson Land (East Greenland). Meddr Grønland, $\mathrm{Bd} .87, \mathrm{Nr} .7$.

Stauber, H. (1942) Die Triasablagerungen von Ostgrönland. Meddr Grфnland, Bd. $132, \mathrm{Nr} .1$.

Trümpy, R. (1961) Triassic of East Greenland. In Raasch, G. H. (edit.) Geology of the Arctic, Vol. 1, 248-254.

\title{
AN INVESTIGATION OF THE TERTIARY BASALTS IN SCORESBY SUND
}

\section{W. Stuart Watt}

Work on mapping the Tertiary basalts in the western part of the Scoresby Sund area started in the summer of 19.68 as part of the five year project of mapping the whole region. One field party spent six weeks making detailed observations and extensive collections from a number of sections in the basalts.

$1800 \mathrm{~m}$ of the upper part of the basalt succession were examined in an area extending from Kap Stevenson in the east to a nunatak south of the inner part of Gaasefjord in the west and to the southern part of Milne Land 
in the north. Within this area the basalts have a general south of southwesterly dip of about $1^{\circ}$ so that the highest part of the succession is expected to occur on the higher nunataks about $50 \mathrm{~km}$ south of the inner part of Gaasefjord. This uppermost part of the succession was not reached this year.

In general terms the basalts examined are divisible into two main groups according to the amygdale minerals present. The assemblage chalcedony/agate and quartz, together with abundant stilbite and heulandite, characterizes one group, while the assemblage chabazite and thomsonite, with mesolite and calcite, characterizes the other basalt group. According to Walker's observations in eastern Iceland (1960) the first assemblage is associated with tholeiitic basalts and the second with olivine basalts. This implies the lower part of the $1800 \mathrm{~m}$ of the basalt succession examined is a tholeiitic basalt, and that above about 1000 to $1200 \mathrm{~m}$ in altitude the basalt is olivine-bearing. Many of the flows are non-porphyritic on a macroscopic scale, others have small, scattered plagioclase phenocrysts and occasionally also pyroxene phenocrysts.

Pyroclastics were rarely seen and where they do occur they appear to be a local feature. A single sandstone horizon with fossil wood was seen at the height of $1500 \mathrm{~m}$ in one of the sections. It is overlain by a pocket of red sandstone apparently of very local occurrence. No coal has been seen.

Reference

Walker, G.P.L. (1960) Zeolite zones and dike distribution in relation to the structure of the basalts of eastern Iceland. J.Geol., Vol. 68, $515-528$. 